\title{
Potensial redoks tanah sebagai penduga respirasi heterotrof dari lahan gambut perkebunan kelapa sawit di Riau
}

\section{Soil redox potential as predictor of heterotrophic respiration of an oil palm plantation-peatland in Riau}

Bargowo Addianto ${ }^{a}$, Bandung Sahari ${ }^{\mathrm{b}}$, Atang Sutandi ${ }^{\mathrm{c}}$, Untung Sudadi ${ }^{\mathrm{c}}$

a Program Studi Magister Ilmu Tanah, Sekolah Pascasarjana, Institut Pertanian Bogor, Kampus IPB Dramaga Bogor, 16680, Indonesia

b Divisi Sustainabiliti, PT Astra Agro Lestari Tbk., Kawasan Industri Pulogadung, Jakarta, 13930, Indonesia

${ }^{\mathrm{c}}$ Departemen Ilmu Tanah dan Sumberdaya Lahan, Fakultas Pertanian, Institut Pertanian Bogor, Kampus IPB Dramaga, Bogor, 16680, Indonesia

\section{Article Info:}

Received: 20 - 12 - 2018

Accepted: 25 - 03 - 2019

Keywords:

Carbon dioxide flux, heterotrophic component's respiration, soil Eh

\section{Corresponding Author:}

Untung Sudadi

Departemen Ilmu Tanah dan

Sumberdaya Lahan, Fakultas

Pertanian, Institut Pertanian

Bogor;

Tel. +62-251-8629360

Email:

u_sudadi@apps.ipb.ac.id

\begin{abstract}
Soil respiration consists of autotrophic and heterotrophic respiration, in which in a peatland the latter is equivalent to the decomposition of peat material. This study aimed to develop a model of soil redox potential (Eh) as a pedictor of heterotrophic respiration of an oil palm plantation cultivated in tropical peatland. Soil respiration was measured using closed chamber method at close-to-tree $(2 \mathrm{~m}$ distance from the tree) and far-from-tree ( $4.5 \mathrm{~m}$ from the tree) plots, while for heterotrophic one was at root-cut (4.5m from the tree) plots prepared by root-trenching up to $80 \mathrm{~cm}$ depth with 8 months' incubation. Soil respiration of the study site was 40.81 ton $\mathrm{CO}_{2} h a^{-1} \cdot y^{-1}, 50.53 \%$ of which was contributed by respiration from the heterotrophic components (RHC). The latter correlated positively with soil Eh at pH 7 measured at -30 and $-90 \mathrm{~cm}$ depth (Eh7 30 and Eh7 90), and negatively with soil water level. Significant values of simple linear correlation coefficients ( $r=0.838$ and 0.866 , each with $n=12$ ) with $R H C$ were shown by Eh7 30 and Eh7 90, respectively. Therefore, these factors could be suggested as predictors for RHC by equation: $\mathrm{RHC}$ (ton $\mathrm{CO}_{2} \mathrm{ha}^{-1} \cdot \mathrm{y}^{-}$ $\left.{ }^{1}\right)=18.2+0.029$ Eh7 30 + 0.037 Eh7 90 (Eh in $\left.\mathrm{mV}\right)$.
\end{abstract}

How to cite (CSE Style $8^{\text {th }}$ Edition):

Addianto B, Sahari B, Sutandi A, Sudadi U. 2020. Potensial redoks tanah sebagai penduga respirasi heterotrof dari lahan gambut perkebunan kelapa sawit di Riau. JPSL 10(2): 163-172. http://dx.doi.org/10.29244/jpsl.10.2.163-172.

\section{PENDAHULUAN}

Respirasi tanah $\left(\mathrm{R}_{\mathrm{S}}\right)$ atau flux $\mathrm{CO}_{2}$ total tanah terdiri atas respirasi autotrof $\left(\mathrm{R}_{\mathrm{A}}\right)$ dan respirasi heterotrof $\left(\mathrm{R}_{\mathrm{H}}\right)$, masing-masing berasal dari komponen asosiasi akar dan organisme tanah di rizosfer serta aktivitas komponen mikrob dan fauna tanah dalam proses dekomposisi bahan organik pada tanah mineral atau bahan gambut pada tanah organik. Nilai $\mathrm{R}_{\mathrm{H}}$ setara dengan laju dekomposisi bahan gambut yang terjadi dalam kondisi aerob. Oleh sebab itu, flux atau laju emisi bersih $\mathrm{CO}_{2}$ tanah pada lahan gambut dinyatakan berasal dari kontribusi $R_{H}$ (Hergoualc'h dan Verchot, 2013). Namun, beberapa penelitian menggunakan nilai $R_{S}$ sebagai emisi bersih $\mathrm{CO}_{2}$ tanah (Hooijer et al., 2010; Ali et al., 2006; Melling et al., 2005), sehingga diperoleh nilai berlebih (over estimation).

Metode penetapan flux $\mathrm{CO}_{2}$ yang telah disepakati IPCC (2014) meliputi flux method dan subsidence method. Flux method lebih umum digunakan untuk menentukan pertukaran $\mathrm{CO}_{2}$ pada tanah organik, sedangkan subsidence method merupakan pengukuran laju penurunan permukaan tanah organik akibat 
proses oksidasi terkait drainase. Siklus produksi perkebunan kelapa sawit meliputi rentang umur 25-30 tahun. Penanaman kembali (replanting) dilakukan pada rentang umur tersebut atas dasar ketinggian tanaman yang telah mencapai $>10$ meter sehingga semakin mempersulit proses panen. Budidaya kelapa sawit skala perkebunan di lahan gambut mencapai puncak produktivitas pada rentang umur 11 sampai dengan 20 tahun setelah tanam (Corley dan Tinker, 2013), sehingga tanaman pada umur 14 tahun sangat sesuai untuk dijadikan pewakil dalam penetapan rerata flux $\mathrm{CO}_{2}$ dari satu siklus budidaya di lahan gambut. Dengan jarak tanam $9 \mathrm{~m}$, tajuk kelapa sawit berumur 14 tahun telah saling tumpeng-tindih (overlapping).

Flux $\mathrm{CO}_{2}$ dari perkebunan kelapa sawit pada lahan gambut lebih tinggi daripada lahan gambut dengan vegetasi semak belukar (Sarmah et al., 2014) dan semakin tinggi dengan bertambahnya umur (PPKS, 2016). Nilai $\mathrm{R}_{\mathrm{A}}$ kelapa sawit memiliki proporsi relatif 38-74\% terhadap $\mathrm{R}_{\mathrm{S}}$ (Sabiham et al., 2014; Agus et al., 2010). Pengukuran flux $\mathrm{CO}_{2}$ secara langsung, rumit dan membutuhkan waktu pengamatan yang lama yaitu bulanan hingga tahunan. Oleh sebab itu, para peneliti terus mencari parameter penduga dan mengembangkan model atau persamaan spesifik hubungan antara parameter tersebut dengan flux $\mathrm{CO}_{2}$ sebagai metode undirect measurement. Posisi muka air tanah gambut digunakan oleh Hooijer et al. (2010) dan menghasilkan model linier "Emisi $\mathrm{CO}_{2}$ (ton $\mathrm{CO}_{2}$ ha $\left.^{-1} \cdot \mathrm{th}^{-1}\right)=91 \mathrm{x}$ muka air tanah $(\mathrm{m})$ " dengan nilai koefisien determinasi $\left(\mathrm{R}^{2}\right) 0.71$ dari 8 pasangan data. Nilai estimasi flux $\mathrm{CO}_{2}$ yang diperoleh dari persamaan tersebut dianggap tidak relevan karena terlalu berlebih (overestimated). Hubungan antar kedua parameter tersebut juga masih menunjukkan inkonsistensi, yaitu bersifat signifikan positif (Dariah et al., 2013a; Moore dan Dalva, 1993), signifikan negatif (Hirano et al., 2014; Sarmah et al., 2014; Furukawa et al., 2005), atau tidak signifikan (Jauhiainen et al., 2008). Inkonsistensi tersebut menunjukkan lemahnya tingkat hubungan dan keterkaitan antara tinggi muka air tanah dengan flux $\mathrm{CO}_{2}$, terutama apabila nilai flux $\mathrm{CO}_{2}$ yang digunakan adalah hasil pengukuran respirasi tanah $\left(\mathrm{R}_{\mathrm{S}}\right)$.

Menurut Holden et al. (2004), laju dekomposisi bahan gambut dipengaruhi oleh beberapa sifat bahan gambut dan faktor lingkungan, yaitu potensial redoks (Eh), $\mathrm{pH}$, dan suhu tanah. Faktor lingkungan tersebut juga memengaruhi aktivitas mikrob tanah. Nilai Eh sebagai parameter perubahan kadar oksigen pada tiap lapisan tanah organik menentukan laju dekomposisi atau oksidasi bahan gambut, sehingga Eh tanah diduga memiliki hubungan yang erat dengan produksi $\mathrm{CO}_{2}$ dari proses $\mathrm{R}_{\mathrm{H}}$. Penelitian ini bertujuan mengembangkan model potensial redoks (Eh) tanah sebagai penduga respirasi heterotrof dari perkebunan kelapa sawit pada umur puncak produktivitas di lahan gambut tropika.

\section{METODE}

\section{Lokasi dan Waktu Penelitian}

Penelitian dilakukan mulai Juni 2018 sampai dengan Mei 2019. Lokasi penelitian terletak di perkebunan kelapa sawit PT. Kimia Tirta Utama di Desa Pangkalan Pisang, Kecamatan Koto Gasib, Kabupaten Siak, Provinsi Riau, pada koordinat sekitar 040'56.698” LU dan 10146’20.791” BT. Plot penelitian terletak di bagian tengah blok OE12, OE13, dan OE14 kebun kelapa sawit berumur 14 tahun serta diasumsikan mewakili keragaman ketebalan lapisan gambut. Blok OE12 sebagai pewakil gambut sangat dalam (3-5 m), blok OE13 mewakili gambut sedang $(1-3 \mathrm{~m})$, dan blok OE14 mewakili gambut dangkal $(<1 \mathrm{~m})$. Plot penelitian terletak dibagian tengah masing-masing blok, dengan jarak berkisar $150 \mathrm{~m}$ dari saluran drainase. Peletakan plot penelitian didasarkan oleh pendapat Pulunggono et al. (2019) bahwa flux $\mathrm{CO}_{2}$ tertinggi diperoleh pada jarak terjauh dibandingkan jarak terdekat dari saluran drainase. Pengukuran flux $\mathrm{CO}_{2}$ dan Eh tanah dilakukan langsung di lapangan (in situ). 


\section{Metode Pengumpulan Data}

Pengukuran Eh tanah dilakukan bersamaan dengan pengukuran $\mathrm{pH}$ dan suhu tanah. Sensor Eh dipasang pada tiga posisi sungkup, yaitu pada kedalaman -30, -60, dan $-90 \mathrm{~cm}$ (Gambar 1). Sebelum pemasangan, seluruh sensor Eh dikalibrasi dan dilakukan pencatatan nilai Eh dari elektroda referensi $\left(\mathrm{Eh}_{\mathrm{Ag} / \mathrm{AgCl}}\right)$. Larutan kalibrasi yang digunakan adalah 1 gr quinhydrone dalam $100 \mathrm{~mL}$ larutan buffer $\mathrm{pH} 4$ dan $\mathrm{pH} 7$ yang diaduk menggunakan magnetic stirrer selama 15 menit. Larutan quinhydrone hanya dapat digunakan selama 7 jam sejak dibuat (Striggow, 2013). Nilai Eh larutan quinhydrone pada pH 4 dan pH 7 masing-masing adalah 462 dan $285 \mathrm{mV}\left(25^{\circ} \mathrm{C}\right)$. Nilai $\mathrm{Eh}_{(\mathrm{Ag} / \mathrm{AgCl})}$ diperoleh menggunakan persamaan 1.

$$
\mathrm{Eh}_{(\mathrm{Ag} / \mathrm{AgCl})}=\mathrm{Eh}_{\text {quinhydrone }}-\mathrm{Eh}_{\text {pembacaan alat }}
$$

Setelah pemasangan sensor Eh dilakukan pengukuran Eh menggunakan voltmeter (satuan $\mathrm{mV}$ ) dengan cara menghubungkan dua kabel di permukaan tanah (dipasang pada pipa PVC berdiameter 3/4"). Nilai Eh contoh tanah diperoleh dari persamaan 2 .

$$
\mathrm{Eh}_{\text {contoh }}=\mathrm{Eh}_{\text {pembacaan alat }}+\mathrm{Eh}_{(\mathrm{Ag} / \mathrm{AgCl})}
$$

Apabila terjadi perubahan suhu dan $\mathrm{pH}$, nilai $\mathrm{Eh}$ contoh dikoreksi menggunakan persamaan 3, yaitu persamaan Nernst (Reddy dan DeLaune, 2008).

$$
\mathrm{Eh}_{\text {contoh revisi }}=\mathrm{Eh}_{\text {contoh }}-\frac{\mathrm{RT}}{\mathrm{nF}} 2.303 \log \frac{[\text { Reduktan }]}{\text { [Oksidan }]}
$$

dimana $\mathrm{Eh}_{\text {pembacaan alat }}$ adalah Eh hasil pengukuran dengan voltmeter $(\mathrm{mV}), \mathrm{Eh}_{(\mathrm{Ag} / \mathrm{AgCl})}$ adalah Eh elektroda referensi $(\mathrm{mV}), \mathrm{R}$ adalah konstanta gas $\left(8.314 \mathrm{~J}^{\mathrm{K}} \mathrm{K}^{-1} \cdot \mathrm{mol}^{-1}\right), \mathrm{T}$ adalah suhu mutlak $\left({ }^{\circ} \mathrm{K}\right), \mathrm{n}$ adalah valansi ion, dan F adalah konstanta Faraday $\left(9.648 \times 10^{4} \mathrm{C}^{\mathrm{mol}}{ }^{-1}\right)$.

Titik pengamatan Eh, $\mathrm{pH}$, dan suhu tanah berada pada jarak 9 meter dari posisi piezometer. Sungkup PVC untuk pengukuran flux gas $\mathrm{CO}_{2}$ dipasang pada 3 posisi. PVC dengan diameter $25 \mathrm{~cm}$ dan tinggi $50 \mathrm{~cm}$ dibenamkan sedalam $10 \mathrm{~cm}$ pada ketiga posisi sungkup tersebut. Pengukuran respirasi heterotrof $\left(\mathrm{R}_{\mathrm{H}}\right)$ dilakukan pada posisi sungkup RC (root-cut) yang berjarak $4.5 \mathrm{~m}$ dari pohon kelapa sawit dan dilakukan pemotongan akar serta pemasangan plat seng dengan ukuran kotak $100 \mathrm{~cm}$ x $50 \mathrm{~cm}$ hingga kedalaman 80 $\mathrm{cm}$. Pengukuran respirasi total tanah $\left(\mathrm{R}_{\mathrm{S}}\right.$ ) dilakukan pada posisi sungkup CT (close-to-tree) yang berjarak 2 $\mathrm{m}$ dari pohon kelapa sawit dan posisi sungkup FT (far-from-tree) pada jarak $4.5 \mathrm{~m}$ dari pohon kelapa sawit (Gambar 2).

Pengukuran flux $\mathrm{CO}_{2}$ dilakukan dua kali, yaitu pada pagi hari (jam 6.00-8.00 WIB) sebagai pewakil flux $\mathrm{CO}_{2}$ terendah dan siang hari (jam 12.00-14.00 WIB) sebagai pewakil flux $\mathrm{CO}_{2}$ tertinggi. Sebelum pengukuran flux $\mathrm{CO}_{2}$ dilakukan pembersihan gulma secara manual. Penentuan lokasi serta titik pengamatan didasarkan atas prasyarat ketiga pohon kelapa sawit membentuk segitiga sama sisi dan masih tegak berdiri (Gambar 2). Kegiatan pemasangan sungkup dan pemotongan akar untuk perlakuan RC diselesaikan pada akhir Juni 2018 untuk selanjutnya dilakukan inkubasi selama 8 bulan. 

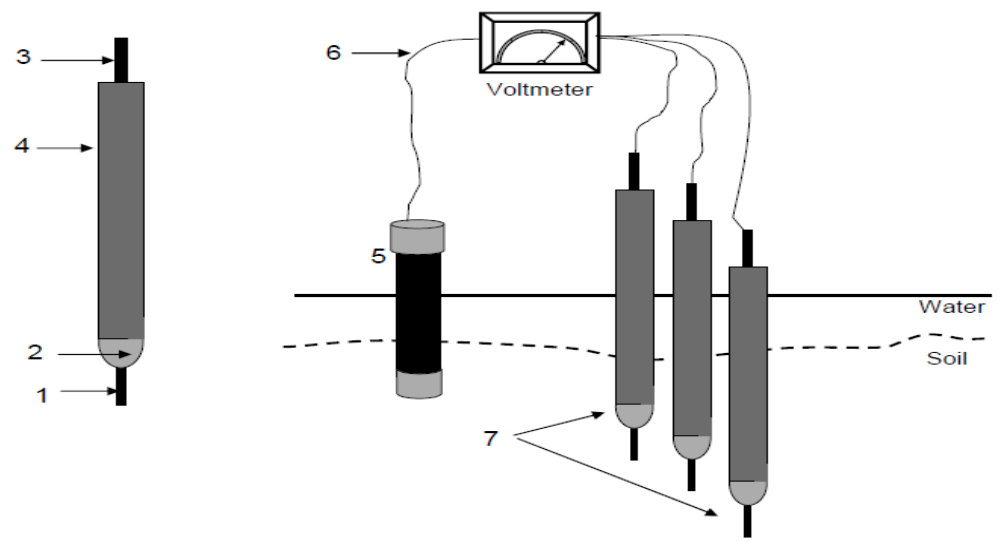

Gambar 1 Skema pembuatan dan pemasangan elektroda redoks di lapangan. (1) kawat platinum $\emptyset 1.1 \mathrm{~mm}$, (2) epoxy tahan air, (3) kawat tembaga $\varnothing 3.18 \mathrm{~mm}$, (4) isolator, (5) elektroda referensi, (6) voltmeter, (7) elektroda platinum (dipasang pada 3 kedalaman lapisan tanah: -30, -60, dan $-90 \mathrm{~cm}$ ).

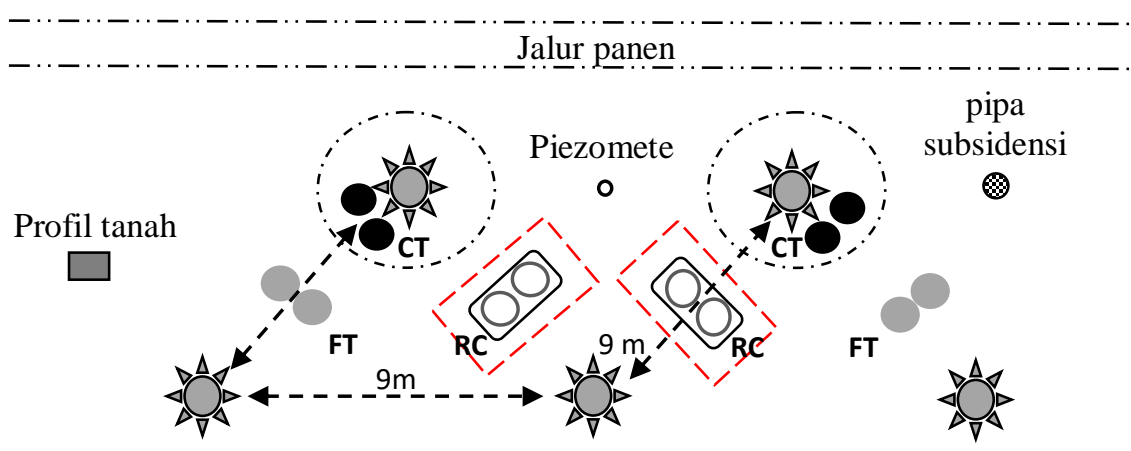

CT: $2 \mathrm{~m}$ dari pohon FT: $4.5 \mathrm{~m}$ dari pohon $\bigcirc \mathrm{RC}: 4.5 \mathrm{~m}$ dari pohon pohon kelapa sawit

Gambar 2 Skema posisi plot pengamatan close-to tree (CT) sebagai pewakil respirasi tanah $\left(\mathrm{R}_{\mathrm{S}}\right)$, far-from-tree $(\mathrm{FT})$ sebagai pewakil $\mathrm{R}_{\mathrm{S}}$, dan root-cut $(\mathrm{RC})$ sebagai pewakil respirasi heterotrof $\left(\mathrm{R}_{\mathrm{H}}\right)$ serta posisi profil tanah, piezometer, dan pipa subsidensi terhadap posisi pohon kelapa sawit pewakil yang membentuk segitiga sama sisi.

Flux $\mathrm{CO}_{2}$ diukur setiap bulan selama empat bulan menggunakan Infrared Gas Analyser (IrGA) Li850

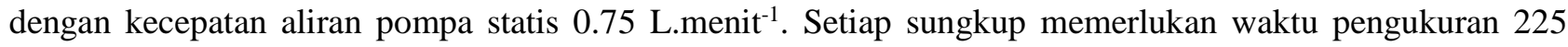
detik (Ishikura et al. 2018). Flux $\mathrm{CO}_{2}$ tanah ( $\left.\mathrm{R}_{\mathrm{S}}\right)$ dihitung dari peningkatan konsentrasi $\mathrm{CO}_{2}$ dalam sungkup pada detik ke 90-220 setelah sungkup ditutup menggunakan persamaan 4.

$$
\mathrm{F}=\frac{P H}{R T_{\text {udara }}} \frac{d C}{d t}
$$

dengan $\mathrm{F}$ adalah flux $\mathrm{CO}_{2}\left(\mu \mathrm{mol} . \mathrm{m}^{-2} . \mathrm{s}^{-1}\right), \mathrm{P}$ adalah tekanan udara $(101.325 \mathrm{kPa}), \mathrm{H}$ adalah tinggi sungkup dari permukaan tanah $(\mathrm{cm}), \mathrm{R}$ adalah konstanta gas $\left(8.314 \mathrm{~Pa}^{3} \mathrm{~m}^{3} \cdot \mathrm{K}^{-1} \cdot \mathrm{mol}^{-1}\right), \mathrm{T}_{\text {udara }}$ adalah suhu udara $\left({ }^{\circ} \mathrm{K}\right)$ dan $\mathrm{dC} / \mathrm{dt}$ adalah laju peningkatan konsentrasi $\mathrm{CO}_{2}$. Kontribusi respirasi heterotrof $\left(\mathrm{R}_{\mathrm{H}}\right)$ terhadap respirasi tanah $\left(\mathrm{R}_{\mathrm{S}}\right)$ dihitung menggunakan persamaan 5.

$$
\% \mathrm{R}_{\mathrm{H}}=\frac{\mathrm{RH}}{\mathrm{RS}} \times 100
$$

dengan $\% \mathrm{R}_{\mathrm{H}}$ adalah persentase laju respirasi heterotrof $\left(\mathrm{R}_{\mathrm{H}}\right)$ terhadap respirasi total tanah $\left(\mathrm{R}_{\mathrm{S}}\right)$, masingmasing dalam $\mu$ mol. $\mathrm{m}^{-2} \cdot \mathrm{s}^{-1}$. 
Pengamatan subsidensi permukaan tanah lahan gambut dilakukan pada awal dan akhir periode pengamatan menggunakan bantuan pipa subsidensi yang dipasang dengan cara dibenamkan hingga bagian bawah pipa menyentuh lapisan tanah mineral. Perhitungan kontribusi $\mathrm{R}_{\mathrm{H}}$ terhadap subsidensi permukaan tanah lahan gambut didasarkan atas persamaan 6 (Ishikura et al., 2018).

$$
\mathrm{S}_{\mathrm{RH}}=\frac{\mathrm{R}_{\mathrm{H}} \text { kumulatif }}{10 \cdot \mathrm{BD} \cdot \mathrm{TC}}
$$

Dimana $\mathrm{S}_{\mathrm{RH}}(\mathrm{cm})$ adalah laju subsidensi permukaan tanah lahan gambut akibat $\mathrm{R}_{\mathrm{H}}$, $\mathrm{R}_{\mathrm{Hkumulatif}}$ adalah penjumlahan flux $\mathrm{CO}_{2}$ pada perlakuan RC selama 4 bulan pengukuran $\left(\mathrm{kg} \mathrm{C} . \mathrm{m}^{-2} \cdot \mathrm{th}^{-1}\right), \mathrm{BD}$ adalah bulk density atau bobot isi bahan gambut (ton. $\left.\mathrm{m}^{-3}\right)$, dan TC adalah kadar karbon dari bahan gambut ( $\mathrm{g} \mathrm{C}^{-1} \mathrm{~g}^{-1}$ )

\section{Analisis Data}

Data flux $\mathrm{CO}_{2}$, Eh, dan posisi muka air tanah diolah menggunakan fasilitas pivot table yang tersedia pada Microsoft Excel versi 2007. Uji normalitas dan transformasi data dilakukan agar memenuhi prasyarat aplikasi analisis statistik parametrik. Analisis ragam (ANOVA) dan perbandingan berganda Tukey digunakan sebagai uji beda nyata flux $\mathrm{CO}_{2}$ akibat perbedaan posisi plot pengukuran sebagai perlakuan. Analisis regresi dan korelasi linier sederhana dan berganda dilakukan untuk mengetahui hubungan dan keterkaitan antara flux $\mathrm{CO}_{2}$ sebagai $\mathrm{R}_{\mathrm{H}}$ dengan Eh dan posisi muka air tanah menggunakan perangkat lunak Genstat versi 18 dan Statistix versi 9.

\section{HASIL DAN PEMBAHASAN}

\section{Posisi muka air tanah}

Posisi muka air tanah pada blok OE12 dan OE14 cenderung lebih rendah dibandingkan blok OE13 yang mampu dipertahankan di atas $-60 \mathrm{~cm}$ dan di ketiga blok pengamatan mencapai posisi terendah pada Maret 2019 (Gambar 3). Pada April 2019, ketiga plot mengalami peningkatan muka air tanah akibat tingginya curah hujan, yaitu $196 \mathrm{~mm}$. Menurut klasifikasi Oldeman, bulan dengan curah hujan <100 mm diklasifikasikan sebagai bulan kering dan sebagai bulan basah jika curah hujan $>100 \mathrm{~mm}$. Berdasarkan data penakar hujan otomatis, curah hujan di lokasi penelitian sejak Juni 2018 hingga Mei 2019 selalu >100 mm, sehingga tidak terdapat bulan kering yang tegas selama periode pengamatan (Gambar 3).

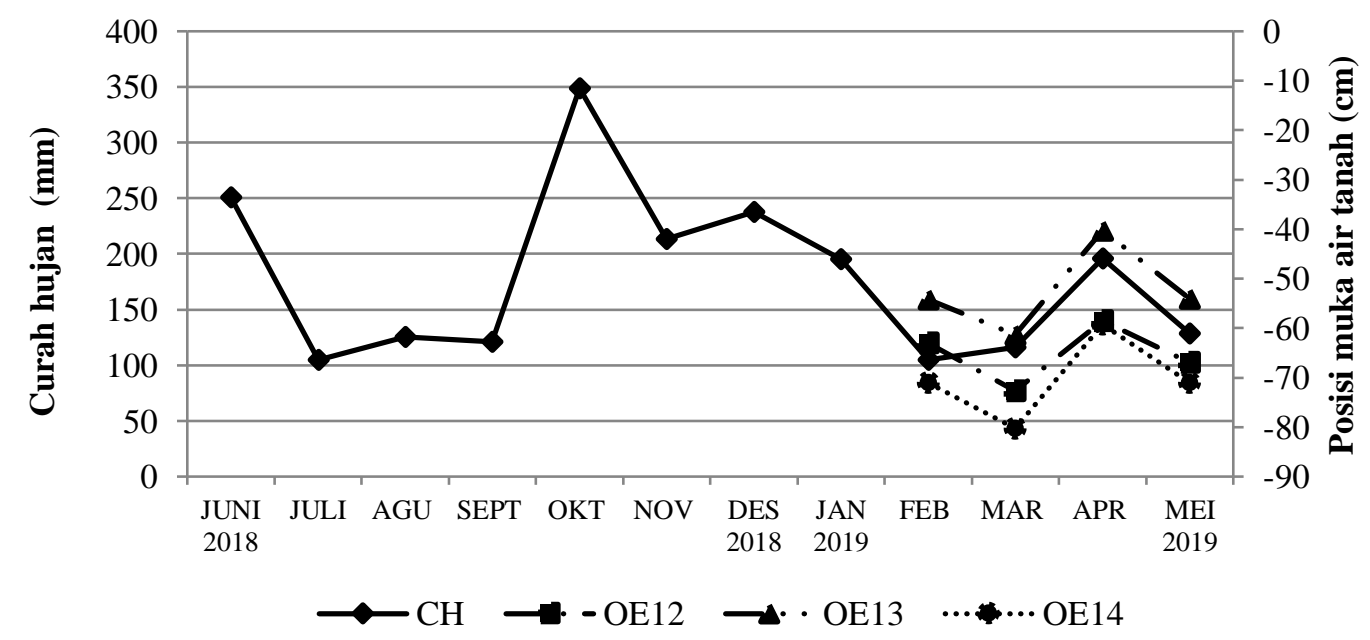

Gambar 3 Posisi muka air tanah di tiga blok pengamatan dan curah hujan bulanan selama periode pengamatan di lokasi penelitian. 


\section{Flux $\mathrm{CO}_{2}$}

Rerata hasil pengukuran flux $\mathrm{CO}_{2}$ dari Februari hingga Mei 2019, 8 bulan setelah dilakukan pemotongan akar tanaman (trenching), disajikan pada Gambar 4. Dengan waktu inkubasi selama 8 bulan setelah trenching, biomassa akar kelapa sawit diasumsikan telah terdekomposisi maksimal, sesuai dengan yang disarankan oleh Wakhid et al. (2017) dan Ishikura et al. (2018), sehingga pengukuran diasumsikan hanya menghasilkan data $\mathrm{R}_{\mathrm{H}}$. Hasil ANOVA menunjukkan flux $\mathrm{CO}_{2}$ pada blok OE12 dengan ketebalan gambut $5 \mathrm{~m}$ tidak berbeda signifikan antara plot FT $\left(\mathrm{R}_{\mathrm{S}}\right)$ dan $\mathrm{RC}\left(\mathrm{R}_{\mathrm{H}}\right)$, namun perlakuan FT $\left(\mathrm{R}_{\mathrm{S}}\right)$ dan $\mathrm{RC}\left(\mathrm{R}_{\mathrm{H}}\right)$ masingmasing memberikan pengaruh signifikan dibandingkan perlakuan $\mathrm{CT}\left(\mathrm{R}_{\mathrm{S}}\right)$. Pada blok OE13 dengan ketebalan gambut $1.5 \mathrm{~m}$, flux $\mathrm{CO}_{2}$ menunjukkan perbedaan signifikan antar ketiga plot. Pada blok OE14 dengan ketebalan gambut $0.8 \mathrm{~m}$, flux $\mathrm{CO}_{2}$ pada plot $\mathrm{CT}$ hanya menunjukkan perbedaan signifikan dengan plot RC (Gambar 4).

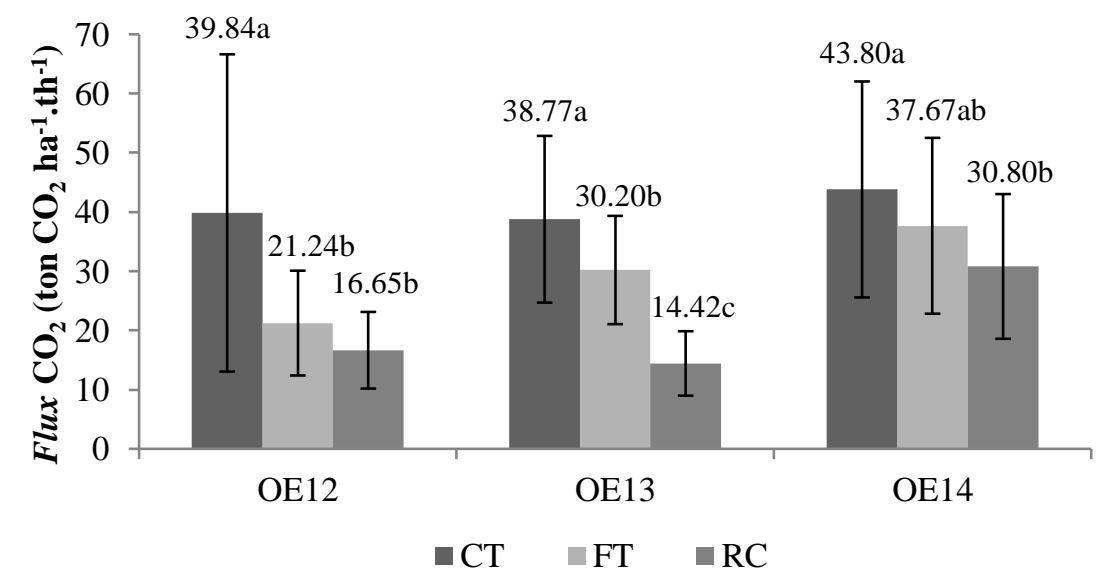

Gambar 4 Rerata flux $\mathrm{CO}_{2}$ selama 4 bulan (Februari-Mei 2019) pada blok CT ( $\mathrm{R}_{\mathrm{S}}$ ),

FT $\left(R_{S}\right)$, dan $R C\left(R_{H}\right)$ (data pada blok dan plot sama dengan huruf sama menunjukkan tidak terjadi perbedaan signifikan pada taraf uji 5\%).

Flux $\mathrm{CO}_{2}$ pada plot RC pada blok OE13 secara signifikan lebih rendah dibandingkan pada blok OE12 dan OE14, namun pada plot CT dan FT tidak berbeda signifikan antar ketiga blok pengamatan. Rendahnya flux $\mathrm{CO}_{2}$ pada plot RC blok OE13 dibandingkan OE12 dan OE14 disebabkan oleh muka air tanah yang lebih tinggi pada blok OE13 dibandingkan pada blok OE12 dan OE14 (Gambar 3).

Secara umum, flux $\mathrm{CO}_{2}$ pada blok OE14 cenderung lebih tinggi dibandingkan pada kedua blok lainnya. Hal ini disebabkan pada blok OE14 terukur muka air tanah yang terendah (Gambar 3) dan pada semester I 2019 diaplikasikan kapur pertanian dengan dosis $149.5 \mathrm{~kg}$.ha- ${ }^{-1}$. Sesuai dengan hasil penelitian Jauhiainen et al. (2014) bahwa peningkatan flux $\mathrm{CO}_{2}$ hingga $2 \%$ terjadi pada lahan yang dipupuk dibandingkan yang tidak dipupuk sebagai akibat dari peningkatan aktivitas mikrob dalam proses dekomposisi bahan gambut. Selain itu, $\mathrm{CO}_{2}$ juga dilepaskan oleh kaptan yang bereaksi dengan tanah gambut (Suharto et al., 2017).

Hasil penelitian ini tidak berkesesuaian dengan hasil penelitian Dariah et al. (2013b) bahwa hasil pengukuran flux $\mathrm{CO}_{2}$ pada posisi sungkup $\geq 3 \mathrm{~m}$ dari pohon kelapa sawit dapat dijadikan sebagai pewakil $\mathrm{R}_{\mathrm{H}}$. Pengukuran flux $\mathrm{CO}_{2}$ pada jarak $\geq 3 \mathrm{~m}$ dari pohon kelapa sawit berumur 14 tahun atau pada umur puncak produktivitas tanaman pada penelitian ini masih mewakili $R_{S}$ atau tidak mewakili $R_{H}$ karena pada posisi antara plot CT dan FT tersebut masih terkonsentrasi ujung-ujung akar dari dua tanaman kelapa sawit yang berdekatan. Berdasarkan temuan tersebut, maka disarankan untuk menerapkan teknik trenching pada jarak $4.5 \mathrm{~m}$ dari pohon hingga kedalaman $80 \mathrm{~cm}$ dan diinkubasi minimal 8 bulan untuk memperoleh hasil pengukuran flux $\mathrm{CO}_{2}$ yang mewakili $\mathrm{R}_{\mathrm{H}}$. 


\section{Kontribusi $\mathbf{R}_{\mathrm{H}}$ terhadap $\mathbf{R}_{\mathrm{S}}$}

Untuk mengetahui persentasi kontribusi $\mathrm{R}_{\mathrm{H}}$ terhadap $\mathrm{R}_{\mathrm{S}}$ maka nilai $\mathrm{R}_{\mathrm{S}}$ dari plot $\mathrm{CT}$ digunakan sebagai pewakil interaksi antara akar tanaman kelapa sawit dengan komponen heterotrof yang mendekomposisi bahan gambut, sedangkan plot RC yang telah menghilangkan kontribusi akar kelapa sawit mewakili nilai $\mathrm{R}_{\mathrm{H}}$ yang hanya dihasilkan dari aktivitas komponen heterotrof dalam proses dekomposisi bahan gambut secara aerob. Rerata kontribusi $\mathrm{R}_{\mathrm{H}}$ terhadap $\mathrm{R}_{\mathrm{S}}$ dari 3 blok pengamatan dengan umur kelapa sawit 14 tahun dan ketebalan gambut beragam di lokasi penelitian adalah 50.53\% (Tabel 1).

Tabel 1 Rerata kontribusi respirasi heterotrof $\left(\mathrm{R}_{\mathrm{H}}\right)$ terhadap respirasi tanah $\left(\mathrm{R}_{\mathrm{S}}\right)$ dari perkebunan kelapa sawit berumur 14 tahan pada lahan gambut tropika dengan ketebalan gambut beragam.

\begin{tabular}{ccccc}
\hline No & Blok & $\begin{array}{c}\text { Ketebalan Gambut } \\
(\mathrm{m})\end{array}$ & $\begin{array}{c}\mathrm{R}_{\mathrm{H}} \\
\left(\text { ton } \mathrm{CO}_{2} \mathrm{ha}^{-1} \cdot \mathrm{th}^{-1}\right)\end{array}$ & $\begin{array}{c}\text { Proporsi } \mathrm{R}_{\mathrm{H}} \text { terhadap } \mathrm{R}_{\mathrm{S}} \\
(\%)\end{array}$ \\
\hline 1 & OE12 & 5 & 16.65 & 41.79 \\
2 & OE13 & 1.5 & 14.42 & 37.19 \\
3 & OE14 & 0.8 & 30.80 & 70.32 \\
\hline Rerata & & & 20.62 & 50.53 \\
\hline
\end{tabular}

\section{Kontribusi $\mathbf{R}_{\mathbf{H}}$ terhadap laju subsidensi}

Laju subsidensi permukaan lahan gambut di lokasi penelitian 1.3-2.5 $\mathrm{cm}^{-\mathrm{th}^{-1}}$. Subsidensi permukaan lahan gambut merupakan hasil kombinasi dari pengaruh proses konsolidasi, pemadatan, dan dekomposisi bahan gambut $\left(\mathrm{R}_{\mathrm{H}}\right)$. Laju subsidensi permukaan lahan gambut yang diperoleh dari pengukuran menggunakan pipa subsidensi umumnya lebih besar dibandingkan dengan hasil perhitungan $\mathrm{S}_{\mathrm{RH}}$. Pada blok OE13 diperoleh rerata nilai $S_{R H}$ dari tiap lapisan $1.6 \mathrm{~cm} \cdot \mathrm{th}^{-1}$, sehingga $\mathrm{R}_{\mathrm{H}}$ berkontribusi $64 \%$ terhadap laju subsidensi permukaan lahan gambut (Tabel 2). Namun pada blok OE12 dan OE14, data kontribusi $R_{H}$ terhadap $S_{R H}$ yang diperoleh tidak wajar, yaitu masing-masing sebesar $176 \%$ dan $162 \%$. Hal ini berkaitan dengan rendahnya muka air tanah sehingga diduga memberikan peluang bagi rayap untuk berkembang dan berkontribusi terhadap proses dekomposisi bahan gambut dan sisa biomasa tanaman di lapisan aerob dan menghasilkan nilai $\mathrm{R}_{\mathrm{H}}$ yang semakin tinggi. Flux $\mathrm{CO}_{2}$ pada lahan gambut yang memiliki koloni rayat dapat mencapai 2 kali lipat daripada yang tanpa rayap (Konaté et al., 2003). Metabolisme rayap pemakan kayu mencapai 2 kali lipat daripada rayap pemakan tanah (Pequeno et al., 2016). Di blok OE12 dan OE14 ditemukan sarang rayap pada saat dilakukan pembuatan profil mini pit (Gambar 2). Kayu-kayu yang telah lama terbenam menjadi sumber makanan dan sarang bagi rayap.

Tabel 2 Kontribusi respirasi heterotrof $\left(\mathrm{R}_{\mathrm{H}}\right)$ terhadap subsidensi permukaan lahan perkebunan kelapa sawit berumur 14 tahan pada lahan gambut tropika dengan ketebalan gambut beragam.

\begin{tabular}{|c|c|c|c|c|c|c|c|}
\hline No & Blok & $\begin{array}{c}\text { Ketebalan } \\
\text { Gambut } \\
(\mathrm{m})\end{array}$ & $\begin{array}{c}\mathrm{BD} \\
\text { (ton. } \mathrm{m}^{-3} \text { ) }\end{array}$ & $\begin{array}{l}\text { C-org } \\
\left(\text { g. } g^{-1}\right)\end{array}$ & $\begin{array}{c}\mathrm{S}_{\mathrm{RH}} \\
\left(\mathrm{cm} \cdot \mathrm{th}^{-1}\right)\end{array}$ & $\begin{array}{l}\text { Subsidensi } \\
\left(\mathrm{cm} \cdot \mathrm{th}^{-1}\right)\end{array}$ & $\begin{array}{c}\text { Proporsi } \mathrm{S}_{\mathrm{RH}} \\
\text { terhadap subsidensi } \\
(\%)\end{array}$ \\
\hline 1 & OE12 & 5 & 0.13 & 0.57 & 2.3 & 1.3 & 176 \\
\hline 2 & OE13 & 1.5 & 0.18 & 0.49 & 1.6 & 2.5 & 64 \\
\hline 3 & OE14 & 0.8 & 0.18 & 0.50 & 3.5 & 2.1 & 167 \\
\hline \multicolumn{2}{|c|}{ Rerata } & & & & 2.5 & 2.0 & 125 \\
\hline
\end{tabular}

BD: bulk density, C-org: kadar karbon organik, $\mathrm{S}_{\mathrm{RH}}$ : subsidensi akibat respirasi heterotrof $\left(\mathrm{R}_{\mathrm{H}}\right)$ 
Laju subsidensi dapat digunakan untuk menduga waktu yang dibutuhkan hingga lapisan gambut habis terdekomposisi. Dengan rerata $S_{\mathrm{RH}} 1.3,2.5$, dan $2.1 \mathrm{~cm} . \mathrm{th}^{-1}$ (Tabel 2) dan asumsi tidak ada penambahan bahan organik, maka lapisan gambut pada blok OE12 (ketebalan $5 \mathrm{~m})$, OE13 (1.5 m), dan OE14 (0.8 m) bertutut-turut diprediksi akan hilang dalam 200, 60, dan 32 tahun mendatang.

\section{Eh tanah sebagai penduga flux $\mathrm{CO}_{2}$}

Analisis korelasi Pearson antara flux $\mathrm{CO}_{2}$ pada plot RC atau $\mathrm{R}_{\mathrm{H}}$ dengan Eh-pH 7 pada kedalaman $30 \mathrm{~cm}$ (Eh7 30), (Eh7 90), dan muka air tanah yang melibatkan 12 pasangan data menghasilkan koefisien korelasi tertinggi pada kondisi bulan Maret 2019, berturut-turut dengan nilai $r=0.915(p=0.0007), 0.931 \quad(p=$ 0.0003 ), dan -0.808 ( $p=0.0213$ ). Pada kondisi bulan Maret 2019 dengan curah hujan $116 \mathrm{~mm}$ (Gambar 3), muka air tanah berada pada posisi terendah atau tanah berada pada kondisi paling oksidatif selama periode pengukuran (Februari sampai Mei 2019). Berdasarkan nilai p, maka parameter Eh7 30, Eh7 90, dan muka air tanah berpotensi digunakan sebagai penduga $\mathrm{R}_{\mathrm{H}}$. Hasil analisis lebih lanjut menggunakan model regresi linier berganda yang melibatkan ketiga parameter tersebut sebagai peubah bebas $(X)$ dan $\mathrm{R}_{\mathrm{H}}$ sebagai peubah tak-bebas (Y) dengan 12 pasangan data hasil pengukuran bulan Maret 2019 menghasilkan persamaan terbaik (best fit model) sebagai berikut:

$$
\mathrm{R}_{\mathrm{H}}=18.2+0.029(E h 7 \sim 30)+0.037(E h 7 \sim 90) \quad\left(\mathrm{R}^{2}=0.848, \mathrm{p}=0.0002, \mathrm{n}=12\right)
$$

Dengan demikian, persamaan ini dapat digunakan sebagai model penduga $\mathrm{R}_{\mathrm{H}}$ berdasarkan hasil pengukuran Eh7 30 dan Eh7 90 di lokasi penelitian.

Hasil penelitian ini menunjukkan bahwa posisi plot dan pra-perlakuan trenching menentukan secara signifikan kesahihan hasil pengukuran flux $\mathrm{CO}_{2}$ terkait dengan fenomena peningkatan pertumbuhan dan sebaran perakaran dengan penambahan umur kelapa sawit. Nilai $\mathrm{R}_{\mathrm{H}}$ yang diperoleh dari penelitian ini lebih rendah dibandingkan hasil penelitian Dariah et al. (2013b) dan Agus et al. (2010). Hal ini menunjukkan bahwa hasil-hasil penelitian sejenis bersifat spesifik lokasi.

\section{SIMPULAN}

Rerata flux $\mathrm{CO}_{2}$ pada plot berjarak $4.5 \mathrm{~m}$ dari pohon kelapa sawit dengan pra-perlakuan trenching inkubasi 8 bulan sebagai respirasi komponen heterotrof atau $\mathrm{R}_{\mathrm{H}}$ dari lahan gambut perkebunan kelapa sawit berumur 14 tahun dengan kisaran muka air tanah -40 sampai dengan $-80 \mathrm{~cm}$ adalah 20.62 ton $\mathrm{CO}_{2} \mathrm{ha}^{-1} \cdot \mathrm{th}^{-1}$ dan berkontribusi $50.53 \%$ terhadap respirasi total tanah atau $\mathrm{R}_{\mathrm{S}}$. Pra-perlakuan trenching perlu dilakukan dalam pengukuran $\mathrm{R}_{\mathrm{H}}$ pada lahan gambut perkebunan kelapa sawit pada umur puncak produktivitas untuk menihilkan pengaruh respirasi akar. Model regresi linier berganda $R_{H}=18.2+0.029(E h 7 \sim 30)+0.037(E h 7 \sim 90)$ $\left(\mathrm{R}^{2}=0.848, \mathrm{p}=0.0002, \mathrm{n}=12\right)$ sahih digunakan untuk memprediksi $\mathrm{R}_{\mathrm{H}}$ melalui metode undirect measurement di lokasi penelitian.

\section{DAFTAR PUSTAKA}

Agus F, Handayani E, van Noordwijk M, Idris K, Sabiham S. 2010. Root respiration interferes with peat $\mathrm{CO}_{2}$ emission measurement. In $19^{\text {th }}$ World Congress of Soil Science, Soil Solutions for a Changing World. [Internet]. [diunduh 21 Februari 2018]: Brisbane, Australia. Tersedia pada: https://www.researchgate.net/publication/268328690_Root_respiration_interferes_with_peat_CO_2_e mission_measurement.

Ali M, Taylor D, Inubushi K. 2006. Effects of environmental variations on $\mathrm{CO}_{2}$ efflux from a tropical peatland in eastern Sumatra. Wetlands. 26(2): 612-618. 
Corley RHV, Tinker PB. 2016. The Oil Palm. $5^{\text {th }}$ ed. UK: Wiley Blackwell.

Dariah A, Agus F, Susanti E, Jubaedah. 2013a. Relationship between sampling distance and carbon dioxide emission under oil palm plantation. J Trop Soils 18(2):125-130. doi:10.5400/jts.2013.18.2.125.

Dariah A, Marwanto S, Agus F. 2013b. Root- and peat-based $\mathrm{CO}_{2}$ emissions from oil palm plantations. Mitig Adapt Strat Global Change Biol. 19(6): 831-843. doi10.1007/s11027-013-9515-6.

Furukawa Y, Inubushi K, Ali M, Itang AM, Tsuruta H. 2005. Effect of changing groundwater levels caused by land-use changes on greenhouse gas fluxes from tropical peat lands. Nutr Cycl Agroecosys. 71: 8191. doi:10.1007/s10705-004-5286-5.

Hergoualc'h K, Verchot LV. 2013. Greenhouse gas emission factors for land use and land-use change in Southeast Asian peatlands. Mitig Adapt Strat Global Change Biol. 19: 789-807.

Hirano T, Kusin K, Limin S, Osaki M. 2014. Carbon dioxide emissions through oxidative peat decomposition on a burnt tropical peatland. Glob. Change Biol. 20: 555-565.

Holden J, Chapman PJ, Labadz JC. 2004. Artificial drainage of peatlands: Hydrological and hydrochemical process and wetland restoration. Progr Phys Geography. 28(1): 95-123. doi:10.1191/ 0309133304pp403ra.

Hooijer A, Page S, Canadell JG, Silvius M, Kwadijk J, Wösten H, Jauhiainen J. 2010. Current and future $\mathrm{CO}_{2}$ emissions from drained peatlands in Southeast Asia. Biogeosci. 7(5): 1505-1514. doi:10.5194/bg7-1505-2010.

[IPCC] Intergovernmental Panel on Climate Change. 2014. 2013 Supplement to the 2006 IPCC Guidelines for National Greenhouse Gas Inventories: Wetlands, Hiraishi T, Krug T, Tanabe K, Srivastava N, Baasansuren J, Fukuda M, Troxler TG (eds). Switzerland (CH): IPCC.

Ishikura K, Hirano T, Okimoto Y, Hirata R, Kiew F, Melling L, Aeries EB, Lo KS, Musin KK, Waili JW, Wong GX, Ishii Y. 2018. Soil carbon dioxide emissions due to oxidative peat decomposition in an oil palm plantation on tropical peat. J Agric Ecosyst Environ. 254: 202-212. doi.org/10.1016/j.agee. 2017.11.025.

Jauhiainen J, Kerojoki O, Silvennoinen H, Limin S, Vasander H. 2014. Heterotrophic respiration in drained tropical peat is greatly affacted by temperature-a passive ecosystem cooling experiment. Environ Res Lett. 9(10): 105013-105030. doi: 10.1088/1748-9326/9/10/105013.

Jauhiainen J, Limin S, Silvennoinen H, Vasander H. 2008. Carbon dioxide and methane fluxes in drained tropical peat before and after hydrological restoration. Ecology. 89(12):3503-3514.

Konaté S, Le Roux X, Verdier B, Lepage M. 2003. Effect of underground fungus-growing termites on carbon dioxide emission at the point- and landscape-scales in an African savanna. Functional Ecology. 17: 305-314.

Melling L, Hatano R, Goh KJ. 2005. Soil $\mathrm{CO}_{2}$ flux from three ecosystems in tropical peatland of Sarawak, Malaysia. Tellus. 57B: 1-11.

Moore TR, Dalva M. 1993. The influence of temperature and water table position on carbon dioxide and methane emissions from laboratory columns of peatland soils. J Soil Sci. 44: 651-664.

Paqueno PACL, Baccaro FB, Souza JLP, Franklin E. 2016. Ecology shapes metabolic and life history scalings in termites. Ecol Entomol. 42(2): 115-124. doi: 10.1111/een.12362.

[PPKS] Pusat Penelitian Kelapa Sawit. 2016. Isu Lingkungan dan Fakta Ilmiah Perkebunan Kelapa Sawit pada Lahan Gambut [Internet]. [diunduh 21 Juli 2011]: Tersedia pada: https://agroklimatologippks.files.wordpress.com/2016/03/rangkuman-isu-ling-kungan-dan-faktakelapa-sawit-di-lahan-gambut-revisi.pdf.

Pulunggono HB, Anwar S, Mulyanto B, Sabiham S. 2019. Dinamika Hara pada Lahan Gambut dengan Penggunaan Lahan Kebun Kelapa Sawit, Semak dan Hutan Sekunder. Jurnal Pengelolaan Sumber Daya Alam dan Lingkungan. 9(3): 692-699. doi:10.29244/jps1.9.3.692-699.

Reddy R, DeLaune RD. 2008. Biogeochemistry of Wetlands: Science and Applications. US: CRC Press. 
Sabiham S, Marwanto S, Watanabe T, Funakawa S, Sudadi U, Agus F. 2014. Estimating the relative contributions of root respiration and peat decomposition to the total $\mathrm{CO}_{2}$ flux from peat soil at an oil palm plantation in Sumatra, Indonesia. Trop Agr Develop. 58(3): 87-93.

Sarmah, Nurhayati, Widyanto H, Dariah A. 2014. Emisi $\mathrm{CO}_{2}$ dari lahan gambut budidaya kelapa sawit (Elaeis guineensis) dan lahan semak belukar di Pelalawan, Riau. Dalam Wihardjaka et al. Prosiding Seminar Nasional Pengelolaan Berkelanjutan Lahan Gambut Terdegradasi untuk Mitigasi Emisi GRK dan Peningkatan Nilai Ekonomi. Jakarta (ID): BPPP Kementan.

Suharto A, Nurrochmat DR, June T. 2017. Neraca karbon pra dan post HTI di blok khusus kesatuan pengelolaan hutan tasik besar serkap Riau. Jurnal Pengelolaan Sumber Daya Alam dan Lingkungan 7(1): 19-28. doi: 10.19081/jpsl.2017.7.1.19.

Striggow B. 2013. Operating Procedure: Field measurement of oxidation-reduction potential (ORP). Georgia (US): USEPA.

Wakhid N, Hirano T, Okimoto Y, Nurzakiah S, Nursyamsi D. 2016. Soil carbon dioxide emissions from rubber plantation on tropical peat. Sci Total Environ. 581-582: 857-865. doi:10.1016/j.scitotenv.2017. 01.035 . 